\title{
A STUDY OF TUNICA VAGINALIS FLAP IN ADULT REOPERATIVE HYPOSPADIAS
}

Periasamy Ponnusamy1, Thiruvarul Palanisamy Venkatachalam², Pitchai Balashanmugham Karrupaiah³, Govindarajan Periasamy4, Selvakumar Soman 5 , Kulthe Ramesh Seetharam Bhat ${ }^{6}$

${ }^{1}$ Senior Assistant Professor, Department of Urology, Government Stanley Medical College, Chennai.

${ }^{2}$ Senior Assistant Professor, Department of Urology, Government Stanley Medical College, Chennai.

3 Professor, Department of Urology, Government Stanley Medical College, Chennai.

${ }^{4}$ Professor \& HOD, Department of Urology, Government Stanley Medical College, Chennai.

5 Post Graduate, Department of Urology, Government Stanley Medical College, Chennai.

${ }^{6}$ Post Graduate, Department of Urology, Government Stanley Medical College, Chennai.

ABSTRACT: Hypospadias is a common congenital abnormality and reoperation of failed childhood hypospadias repair is seriously bothersome and is surgeon's nightmares because of lack of abundant penile and prepuce skin for urethroplasty and penile shaft coverage. We assessed the use of tunica vaginalis as an interposing flap over reoperative hypospadias repair. Our study has a 93.75\% success rate (No urine leak) and $6.25 \%$ failure rate (Urine leak) which was comparable to other studies. (71.4\% to $100 \%$. Mean was 93.1\%). Thus, Tunica vaginalis flap reinforcement is an excellent and should always be in mind for reoperative hypospadias, especially when the local genital tissues appears to be scarred, tunica vaginalis flap as a second layer provides a well vasularised cover for adequate healing.

KEYWORDS: Hypospadias, Tunica Vaginalis Flap, Failed Hypospadias Repair.

HOW TO CITE THIS ARTICLE: Periasamy Ponnusamy, Thiruvarul Palanisamy Venkatachalam, Pitchai Balashanmugham Karrupaiah, Govindarajan Periasamy, Selvakumar Soman, Kulthe Ramesh Seetharam Bhat. "A Study of Tunica Vaginalis Flap in adult Reoperative Hypospadias". Journal of Evolution of Medical and Dental Sciences 2015; Vol. 4, Issue 91, November 12;

Page: 15624-15629, DOI: $10.14260 /$ jemds/2015/2246.

INTRODUCTION: Hypospadias is most common congenital anomaly of penis. ${ }^{1}$ Surgical correction of proximal hypospadias is technically challenging. Reoperation of failed childhood hypospadias repair is seriously bothersome and is surgeon's nightmares because of lack of abundant penile and prepuce skin for urethroplasty and penile shaft coverage. It is the surgeons' responsibility to answer them because of psychologic trauma of multiple previous procedures and associated expectations. The available techniques have mixed results.

AIM OF THE STUDY: To assess efficacy of tunica vaginalis flap as an interposing layer in reoperative hypospadias.

\section{METHODOLOGY:}

Study Design: Prospective study

Duration: August 2012 to January 2015

Institute: Government Stanley Medical College, Chennai.

\section{PATIENT SELECTION:}

\section{Inclusion Criteria:}

1. Patients with post childhood hypospadias repair urethrocutaneous fistula.

Financial or Other, Competing Interest: None.

Submission 21-10-2015, Peer Review 22-10-2015,

Acceptance 30-10-2015, Published 10-11-2015.

Corresponding Author:

Periasamy Ponnusamy,

Department of Urology,

$N S B, 6^{\text {th }}$ Floor, Government Stanley Medical College,

Old Jail Road, Royapuram, Chennai-600001,

Tamilnadu, India.

E-mail: drppsamysubha@gmail.com

DOI:10.14260/jemds/2015/2246.
2. Patients with post hypospadias repair long segment penile urethral stricture for which stage I Johanson'surethroplasty was already done.

3. Patients greater than 13 years of age.

\section{Exclusion Criteria:}

1. Cases with previous scrotal surgery (Hydrocele repair or orchidopexy).

2. Cases requiring salvage perineal urethrostomy.

3. Cases with perineal urethro cutaneous fistula.

Pre-operative variables:

- Age.

- Duration of symptoms.

- Uroflowmetry.

- AUG.

- Cystoscopy.

- Previous history of open or endoscopic urethral surgery and dilatation.

- Review of previous operative records.

- Type of Hypospadias.

- Type of initial procedure in childhood.

- Number of fistulae and associated strictures.

- Follow up.

- Operative technique.

For post hypospadias urethrocutaneous fistula, initially urethra was distended with povidone iodine to identify the number of fistulas. The tract is traced to the retubularized urethra and fistulous tract removed. Fistula closed with inverting sutures \& reinforced with tunica vaginalis flap. 
Testis was delivered by a separate scrotal incision and tunica vaginalis flap was harvested which was in turn transferred through a subcutaneous tunnel to fistula site:

- TVF was harvested by incising near testicular inferior pole and tongue of parietal layer of TVF developed with due care to prevent ductus differns and spermatic vessels injury. We must achieve perfect hemostasis and replace testis in to hemiscrotum. Serosal surface of TVF placed over neourethra as interposing layer. 4-0 absorbable tacking stiches done to fix flap to Bucks fascia. Scrotal hemostasis should be achieved.

- For long penile urethra stricture, second stage was done at least 6 months following stage I repair, two asymmetric vertical incisions placed on penile skin on side of the plate and tubularisation done over 16-F silicone urethral catheter by 4-0 polyglactin sutures. An interposing layer of tunica vaginalis was drawn onto neourethra and fixed.

\section{Post-operative - Follow up:}

- UC fistula closure alone - 10th POD - catheter removal.

- Staged repair - 21st POD - catheter removal after performing peri-catheter study.
- Follow up at 3, 6 \& 12 months - Uroflowmetry and if needed AUG and cystoscopy.

\section{Parameters assessed include:} Immediate complications:

- Wound infection.

- Scrotal haematoma.

- Presence of Leak.

- Splaying.

- Delayed complication.

- Meatal stenosis.

- Failure leading to urethrocutaneous fistula and

- Re-operation.

\section{RESULTS:}

Study Group:

Age Distribution: A total of 16 cases (18 to 26 years) of reoperative hypospadias were included.

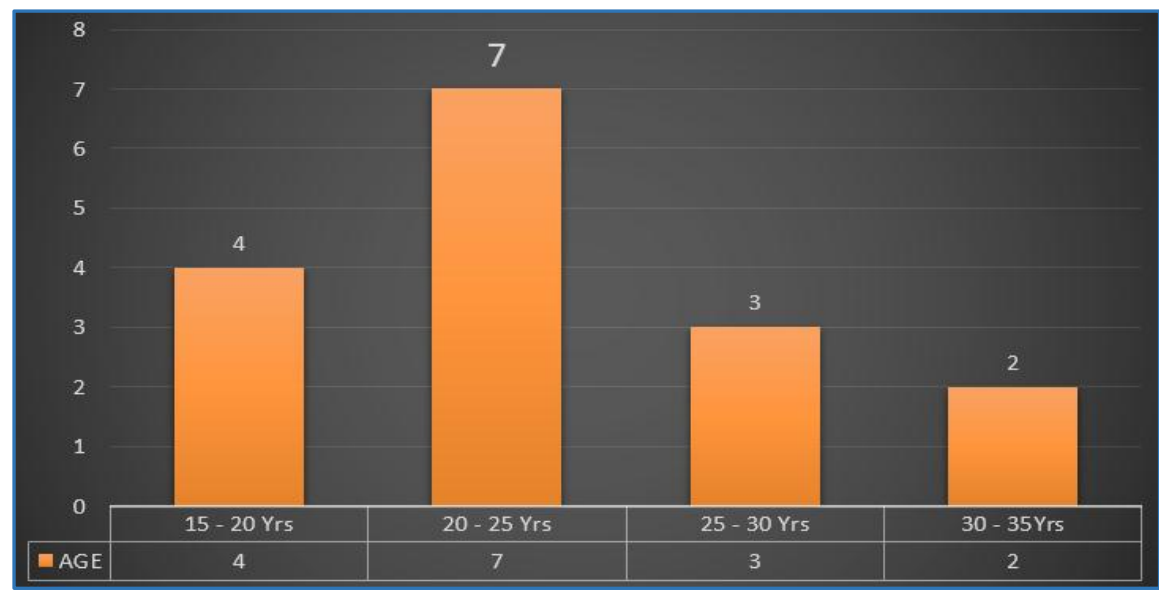

Fig. 1: Age Wise Distribution of Cases.

In all our cases except one there was no apparent scarring of urethral plate.

\begin{tabular}{|c|c|c|}
\hline Clinical Presentation & No. of Cases & Percentage \\
\hline Structure with fistulae & 12 & 75 \\
\hline UC fistula & 4 & 25 \\
\hline \multicolumn{3}{|c|}{ Table 1: Cases at presentation } \\
\hline
\end{tabular}

The initial surgery done in all our cases are shown in the table below.

\begin{tabular}{|c|c|c|c|c|}
\hline $\begin{array}{c}\text { Initial } \\
\text { Procedure } \\
\text { done }\end{array}$ & $\begin{array}{c}\text { Penoscrotal } \\
\text { hypospadias }\end{array}$ & $\begin{array}{c}\text { Proximal } \\
\text { penile }\end{array}$ & $\begin{array}{c}\text { Mid penile } \\
\text { hypospadias }\end{array}$ & Total \\
\hline $\begin{array}{c}\text { Theirsch-duplay } \\
\text { principle }\end{array}$ & 0 & 2 & 6 & 8 \\
\hline $\begin{array}{c}\text { Snodgrass TIP } \\
\text { procedure }\end{array}$ & 0 & 0 & 2 & 2 \\
\hline $\begin{array}{c}\text { Inner preputial skin } \\
\text { tubularisation }\end{array}$ & 2 & 4 & & 6 \\
\hline Total & $\mathbf{2}$ & $\mathbf{6}$ & $\mathbf{8}$ & $\mathbf{1 6}$ \\
\hline \multicolumn{5}{|l}{} \\
Table 2: Initial procedure done for Hypospadias. \\
\hline
\end{tabular}


Total number of prior surgeries are given in the figure below:

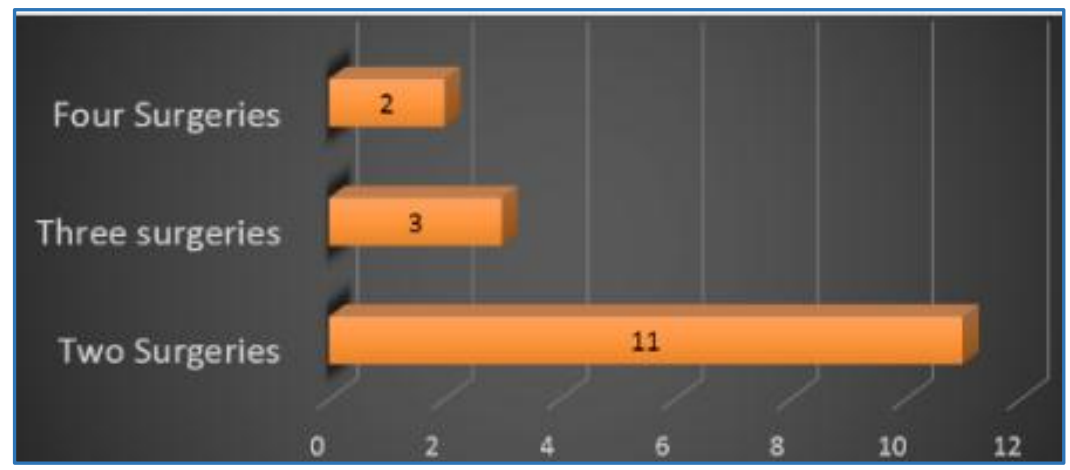

Fig. 2: Number of Surgeries done in patient

Total number of fistulae present in the patients is given below:

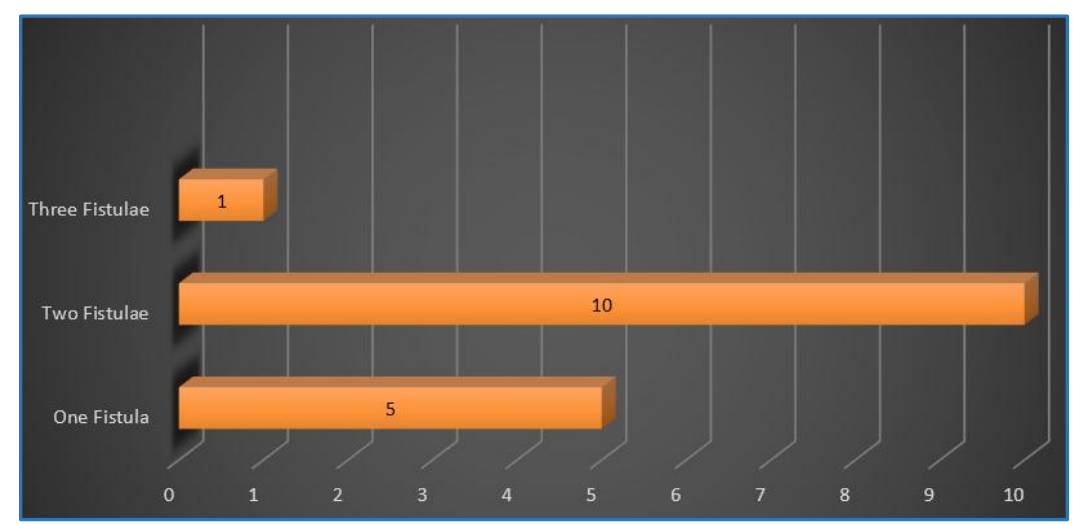

Fig. 3: Number of fistulae in patients.

We performed the following procedure in the study group

\begin{tabular}{|c|c|c|}
\hline Procedure & No. of cases & \% \\
\hline Two stage repair with TVF cover & 12 & 75 \\
\hline Single stage repair with TVF cover & 4 & 25 \\
\hline \multicolumn{2}{|c|}{ Table 3: Procedure done in patient at our centre } \\
\hline
\end{tabular}

In the case with scarred urethral plate-we did Bracka's two stage repair using buccal mucosal graft.All cases had tunica vaginalis flap interposed over the repair.

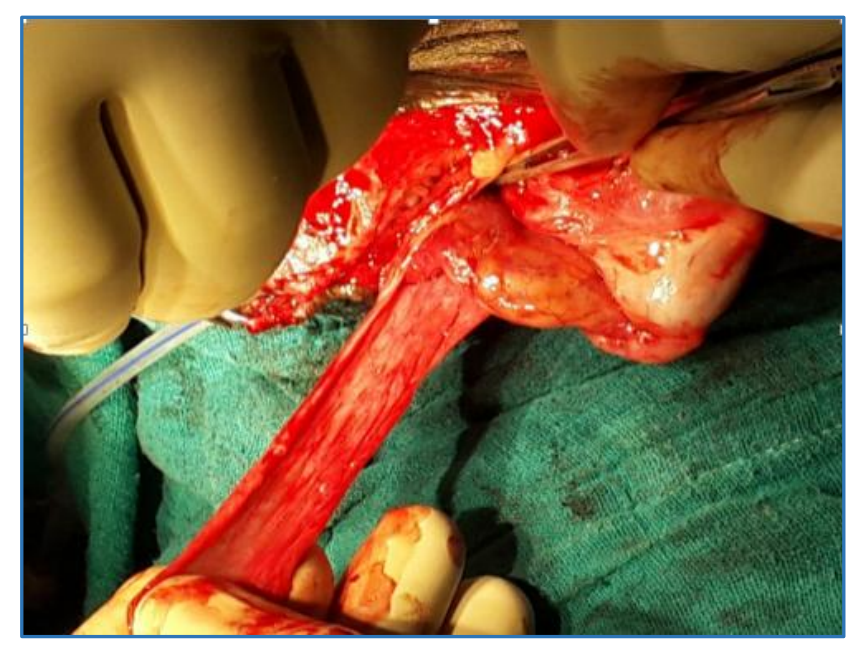

Fig. 4: Harvesting of tunica vaginalis flap 


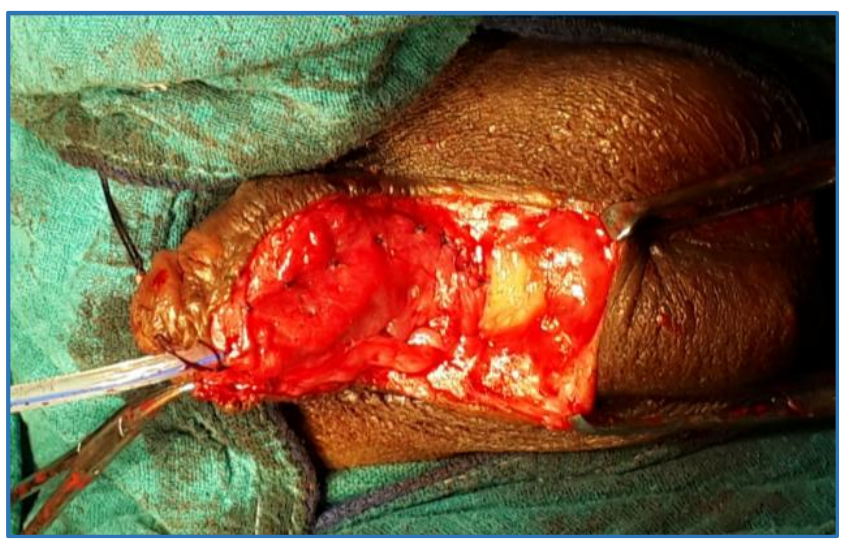

Fig. 5: Tunica vaginalis flap secured over the neo urethra

Outcomes of surgery in our series is shown in figure below:

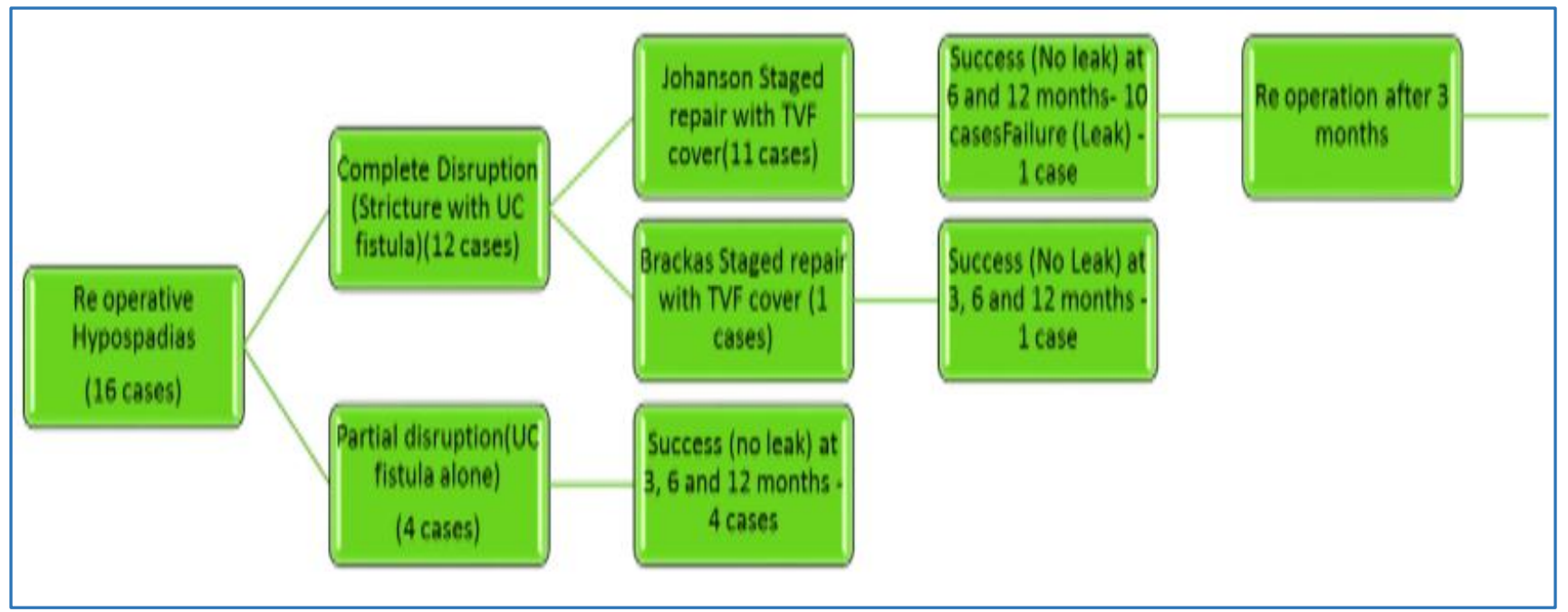

Fig. 6: Flow chart showing patient surgeries and outcomes

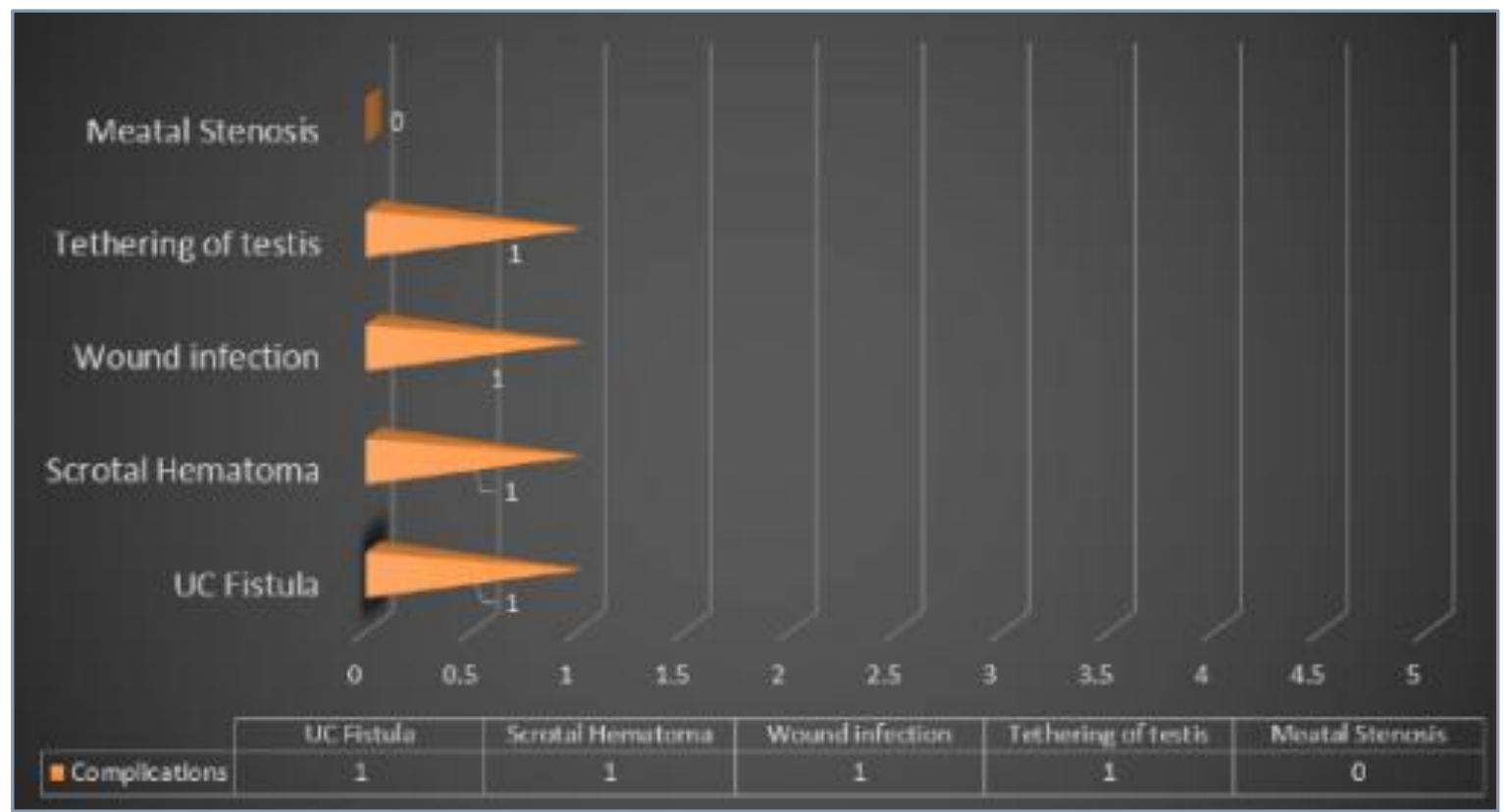

Fig. 7: Complication of surgery in our study

The results of our study was comparable with other studies as shown in the table below. 


\begin{tabular}{|c|c|c|c|c|c|c|c|c|}
\hline \multicolumn{2}{|c|}{ Variables } & $\begin{array}{c}\text { Sharma } \\
\mathrm{N} \text { et } \\
\text { al.10 }\end{array}$ & $\begin{array}{c}\text { Y.S. } \\
\text { Singh } \\
\text { Kadian } \\
\text { et al.11 }\end{array}$ & $\begin{array}{c}\text { Landa } \\
\text { u EH } \\
\text { et al. }{ }^{8}\end{array}$ & $\begin{array}{c}\text { Xue } \\
\text { WY et } \\
\text { al.12 }\end{array}$ & $\begin{array}{l}\text { Routh JC } \\
\text { et al.13 }\end{array}$ & $\begin{array}{c}\text { Ahmed } \\
\text { M. } \\
\text { Khairi } \\
\text { et al.14 }\end{array}$ & $\begin{array}{l}\text { Our } \\
\text { study }\end{array}$ \\
\hline \multicolumn{2}{|c|}{ No. of patients } & 18 & 14 & 14 & 38 & 16 & 14 & 16 \\
\hline \multicolumn{2}{|c|}{ Success (No UC Fistula) } & $\begin{array}{c}17 \\
(94.4 \%) \\
\end{array}$ & $\begin{array}{c}13 \\
(92.8 \%)\end{array}$ & 14 & 38 & 16 & $\begin{array}{c}10 \\
(71.4 \%)\end{array}$ & $\begin{array}{c}15 \\
(93.75 \%)\end{array}$ \\
\hline \multicolumn{2}{|c|}{ Failure (UC Fistula) } & $\begin{array}{c}1 \\
(5.5 \%) \\
\end{array}$ & $\begin{array}{c}1 \\
(7 \%)\end{array}$ & 0 & 0 & 0 & $\begin{array}{c}4 \\
(29.6 \%) \\
\end{array}$ & $\begin{array}{c}1 \\
(6.25 \%) \\
\end{array}$ \\
\hline \multirow{3}{*}{ Complications } & $\begin{array}{c}\text { Scrotal } \\
\text { Hematoma }\end{array}$ & 0 & 1 & 0 & 0 & 0 & 1 & 1 \\
\hline & $\begin{array}{c}\text { Wound } \\
\text { Infection }\end{array}$ & 0 & 0 & 0 & 0 & 0 & 1 & 1 \\
\hline & $\begin{array}{c}\text { Meatal } \\
\text { Stenosis }\end{array}$ & 0 & 0 & 0 & 0 & 0 & 1 & 0 \\
\hline \multicolumn{2}{|c|}{ Follow up months } & 6 & 12 & 44 & 12 & 18 & 9 & 12 \\
\hline
\end{tabular}

DISCUSSION: In spite of improvements in hypospadias surgical techniques, many patients present with failed repairs. Surgical repair of such failed cases is always a challenging undertaking. Most common complication of this failed previous surgeries is urethro cutaneous fistula. Many techniques suggested in these situations like repaired urethra buried in the scrotum..$^{2}$ staged repair. ${ }^{3,4}$ overlapping denuded subcutaneous tissue. ${ }^{4}$ adjacent local spongiosus tissues and rotating skin flaps. ${ }^{5}$

Factors limiting successful outcome are dense scarring, reduced vascularity and lack of prepuce and sufficient penile shaft skin. Dorsal subcutaneous option is not available mostly because it is lost in previous surgeries. But many still continue to use the adjacent genital tissue like dartos as a covering layer.

Snow introduced the tunica vaginalis flap (Parietal layer) to cover the neo-urethra.6,7

The place of this flap in hypospadias surgery is more than that. It is also used for substitution urethroplasty successfully. The advantage in redo cases.8,9 it has its vascular supply from outside source and not rely on vascularity of local genital tissues, which might be scarred or destroyed due to previous repairs. Flap can be developed of sufficient length of the pedicle to cover entire neo-urethra till the distal neo meatus. Dissection of flap is not difficult. Only drawback is that if pedicle length is inadequate, it results in tethering of testis.

After initial hypospadias repair, urethral stricture may occur decades later. Perineal urethrostomy might be the only treatment option for such long segment urethral stricture. This stress the importance of lifelong follow up in such situations to detect such complications at earliest state.

In our study we have assessed the effectiveness of tunica vaginitis flap in preventing urethro cutaneous fistula.

We applied it as an interposing waterproof layer over the neo urethra either after closure of isolated fistula or after second stage repair of the complete urethral disruption.

Our study has $93.75 \%$ success rate (No urine leak) and $6.25 \%$ failure rate (Urine leak). Our success rate was compared to other studies, which was from $71.4 \%$ to $100 \%$. (Mean was 93.1\%)
We followed our case for 12 months. With every visit at $3^{\text {rd }}, 6^{\text {th }}$ and $12^{\text {th }}$ month, none of our patient required AUG or uroflowmetry in the follow up.

LIMITATION OF OUR STUDY: Small sample size (16) with short follow-up duration (12 Months). Large, RCTs with long follow up period is essential to confirm our result and to assess the efficacy of tunica vaginalis flap in urethrocutaneous fistula prevention. However this may not be feasible as only a small subset of patients following hypospadias repair require a reoperation and hence designing such a study may not be possible.

CONCLUSION: Tunica vaginalis flap reinforcement is an excellent and should always be in mind for reoperative hypospadias, especially when the local genital tissues appears to be scarred, tunica vaginalis flap as a second layer provides a well vasularisedcover for adequate healing.

\section{REFERENCES:}

1. Baskin LS. Hypospadias and urethral development. J Urol 2000;163:951-6.

2. Culp OS. Experience with 200 hypospadias: Evolution of a therapeutic plan. SurgClin North Am 1959;39:1007-23.

3. Bracka A. Hypospadias repair: the two-stage alternative. Br J Urol 1995;76:31-41.

4. Snodgrass, Elmore J. Initial WT experience with staged buccal graft (Bracka) hypospadias reoperations. J Urol 2004;172:1720-4.

5. Aslan G, Karg E, Erdogan B. Use of Circular Subcutaneous Tissue Flaps to Prevent Fistulas in Urethroplasty. Annals of Plastic Surgery 2001;46:86-7.

6. Snow BW, Cartwright PC, Unger K. Tunica vaginalis blanket wrap to prevent urethrocutaneous fistula: an 8year experience. The Journal of Urology.1995;153(2):472-473.

7. Snow BW. Use of tunica vaginalis to prevent fistulas in hypospadias surgery. The Journal of Urology. 1986;136(4):861-863.

8. Landau EH, Gofrit ON, Meretyk S, Katz G, Golijanin D, Shenfeld OZ, et al. Outcome analysis of tunica vaginalis flap for the correction of recurrent urethrocuteneous fistula in children. J Urol 2003;170:1596-9. 
9. Voges GE, Reidmiller H, Honenfellner R. Tunica vaginalis free grafts for closure of urethrocutaneous fistula. UrolInt 1990;45:88-99.

10. Sharma N, Bajpai M, Panda SS, Verma A, Sharma M. Tunica vaginalis flap cover in hypospadias cripples: Our experience in a tertiary care center in India. Niger J SurgSci 2014;24:7-11.

11. Kadian YS, Rattan KN, Singh J, Singh M, Kajal P, Parihar D. Tunica vaginalis: An aid in hypospadias fistula repair: Our experience of 14 cases. Afr J PaediatrSurg 2011;8:164-7.

12. Xue WY, Qu CB, Wang XL, Zhang FX, Kang CS. J Urol. 2003 Oct;170(4 Pt 2):1596-9.
13. Routh JC, Wolpert JJ, Reinberg Y. Tunneled tunica vaginalis flap is an effective technique for recurrent urethrocutaneous fistulas following tubularized incised plate urethroplasty,J Urol. 2006 Oct;176(4 Pt 1):157880.

14. Ahmed M. Khairi, Nour El-Kholi, Sherif M. Soliman , Ahmed DemairyTunica Vaginalis Flap; A Feasible Second-Layer for Proximal Hypospadias Re-Do Annals of Pediatric Surgery, Vol3, No 1, January 2007 PP 44-47. 